\title{
NELLY NOVAES
}

COELHO é professora de

Literatura Portuguesa da

FFLCH-USP.

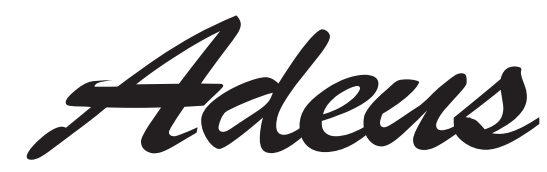

aca

Mestre

NELLY NOVAES COELHO

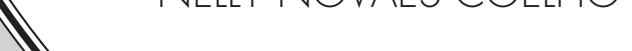


á quanto tempo, Mestre Amora? O primeiro encontro... Parece

que foi ontem, entretanto já lá vão quarenta e tantos anos... A primeira aula de Literatura Portuguesa. 1956. Uma manhã de sol. A sala cheia de calouros, ansiosos, na expectativa dos conhecimentos que os esperavam. Ea presença acolhedora do Mestre que chega, com sua voz amiga e segura, dando boas-vindas e nos falando do mundo literário português que iríamos descobrir, como se falasse de um mundo encantado. Num passeio panorâmico, leva-nos pelos meandros do Romantismo e, nele, destaca um homem, Alexandre Herculano, e um romance, Eurico, o Presbitero (que seria um dos temas do curso). Para nós, um e outro eram quase desconhecidos. Mas aos poucos, na síntese que ia sendo feita pelo Mestre, naquela breve aula, Herculano (o escritor, o político liberal e o exilado) revelou-se de corpo inteiro. E o seu herói, Eurico, o presbítero, nos foi mostrado em suas grandezas e fraquezas, como a figurasímbolo da Fidelidade (fidelidade ao seu dever, aos seus ideais generosos, ao seu amor...).

Hoje, Mestre Amora, diante de sua ausência-presença, veio-me mais uma vez à memória aquela longínqua aula e mais uma vez vejo ressaltar, em sua própria figura, aquela Fidelidade que naquele dia nos revelou, como emblemática no personagem de Herculano. Era com essa grandeza interior que todos nós sempre o vimos, nestes longos anos de convívio humano e intelectual: o grande educador, fiel às suas crenças, companheiros e ideais; o incansável e entusiasta lutador sempre entregue por inteiro à tarefa de abrir caminhos aos que chegavam ou de colaborar com seus pares para a construção do tempo que lhes cabia viver.
Lembra-se, Mestre Amora? Um dia eu lhe disse pessoalmente e agora, na sua ausência-presença, repito: foi realmente um privilégio ter tido a oportunidade de ser sua discípula e depois companheira nas lides docentes. Como aconteceu com tantos outros, foi por sua mão que descobri minha vocação e ingressei na carreira universitária. Sempre com seu generoso estímulo fui vencendo etapa por etapa. Claro que, durante essa caminhada, houve desentendimentos, rusgas, desencontros de opiniões ou decisões (como é possível conviver sem nunca discordar?), mas tudo foi sempre superado, sem mágoas nem cicatrizes. Lembra-se?

Há ainda uma coisa que quero dizerlhe e talvez não precisasse, uma vez que o Mestre já passou para o espaço sem limites, onde supostamente tudo se vê e se sabe... Em todo caso preciso dizer: sua partida (tão doída para todos nós) não deixou nenhum vazio... Na verdade, tudo quanto o Mestre doou de si à tarefa de Vida, de Educador, de Amigo e de Intelectual atento, permanece aqui transformado em obras, em caminhs abertos e multiplicados por um número infindo de companheiros engajados nos mesmos ideais e que também por sua mão se encontraram.

Tarefa cumprida, Mestre Amora!

Tarefa marcada principalmente por um dom que só é dado a raros: a capacidade de admirar. Esse talvez tenha sido um dos segredos de seu grande carisma de Mestre: o saber admirar a grandeza e o valor dos outros e ajudá-los a descobrir que, como dizia Antônio Machado, “o Caminho se fazcaminhando". Ou, no dizer de Fernando Pessoa, “viver não é preciso, navegar é que é preciso". Como grande "caminhante" e "navegante", sua memória segue conosco... Até um dia, Mestre Amora! 